\title{
KEBIJAKAN PEMERINTAH KOTA LANGSA TERHADAP PENGELOLAAN SAMPAH DALAM MEMENUHI PRINSIP GOOD ENVIRONMENTAL GOVERNANCE
}

\author{
Nur Asiyah \\ Dosen Fakultas Hukum Universitas Samudra \\ Meurandeh. Langsa, Aceh - Indonesia \\ nurasiah247@yahoo.co.id
}

\begin{abstract}
Waste management in Indonesia is still waiting for many landfills. Only $60-70 \%$ of the waste can be moved and thrown to the landfill, while it is distributed in various places. The regulation on waste management has been regulated in Law No. 18 of 2008 concerning Waste Management and accommodated in the Langsa City Qanun No. 3 of 2014 concerning Waste management. Each region is able to manage waste well, so implementing the principles of Good Environmental Management has been resolved. This research is a doctrinal / normative legal research with registrant research. Data collected by library research, then analyzed qualitatively. Langsa City has agreed to waste management in Langsa City Qanun No. 03 of 2014 concerning waste management where the policy of providing waste banks and law enforcement in waste management is on 3 legal systems namely structure, substance, and culture. In addition, law enforcement in waste management can be studied from two sides, namely preventive and repressive law enforcement. Waste bank and law enforcement in waste management are also the embodiment of the government or regional government in the application of good environmental management with the aim of raising awareness for the community about a good and healthy environment.
\end{abstract}

\begin{abstract}
Abstrak, Pengelolaan sampah perkotaan di Indonesia masih menghadapi banyak kendala terutama dalam hal keberadaan Tempat Pembuangan Akhir (TPA) atau landfill. Hanya $60-70 \%$ sampah yang dapat terangkut dan dibuang ke TPA, sementara sisanya tersebar diberbagai tempat. Pengaturan mengenai pengelolaan sampah telah diatur dalam UU No. 18 Tahun 2008 tentang Pengelolaan Sampah dan diakomodir dalam Qanun Kota Langsa No 3 Tahun 2014 tentang pengelolaan Sampah. Apabila daerah mampu mengelola sampahnya dengan baik maka pelaksanaan terhadap prinsip Good Environmental Governance sudah dapat dikatakan terpenuhi. Penelitian ini adalah penelitian hukum doktrinal/normatif dengan pendekatan perundang-undangan. Data dikumpulkan dengan studi kepustakaan, kemudian dianalisis secara kualitatif. Kota Langsa telah mengatur prihal pengelolaan sampah dalam Qanun Kota Langsa No. 03 Tahun 2014 Tentang Pengelolaan sampah dimana kebijakan penyediaan bank sampah dan Penegakan hukum dalam pengelolaan sampah mengacu pada 3 sistem hukum yaitu struktur, substansi, dan budaya. Selain itu berkaitan dengan penegakan hukum dalam pengelolaan sampah dapat dikaji dari 2 sisi yaitu penegakan hukum secara preventif dan represif. Bank sampah dan Penegakan hukum dalam pengelolaan sampah juga menjadi sebuah perwujudan pemerintah maupun pemerintah daerah dalam menerapkan prinsip Good Environmental Governance dengan tujuan akan menumbuhkan kesadaran bagi masyarakat akan lingkungan hidup yang baik dan sehat.
\end{abstract}

Kata kunci : Kebijakan Pemerintah, Pengelolaan Sampah, Prinsip Good Environmental Governance 


\section{Pendahuluan}

Sampah adalah sisa kegiatan sehari-hari manusia dan/atau dari proses alam yang berbentuk pada. Laju produksi sampah terus meningkat, tidak saja sejajar dengan laju pertumbuhan penduduk tetapi juga sejalan dengan meningkatnya pola konsumsi masyarakat. Di sisi lain kapasitas penanganan sampah yang dilakukan masyarakat maupun pemerintah daerah belum optimal. Sampah yang tidak dikelola dengan baik akan berpengaruh terhadap lingkungan dan kesehatan masyarakat sekitarnya.

Hal tersebut semakin terasa dampaknya terhadap lingkungan yaitu manusia cenderung merusak lingkungan demi mempertahankan hidupnya. Kualitas lingkungan secara terus menerus semakin menurun sehingga menimbulkan permasalahan degradasi lingkungan pada kehidupan masyarakat. Salah satu permasalahan lingkungan yang masih menjadi problematika di perkotaan yaitu pengelolaan sampah. Menurut Yul H. Harap bahwa sampah merupakan salah satu masalah lingkungan hidup yang sampai saat ini belum dapat ditangani secara baik, terutama pada negara-negara berkembang, sedangkan kemampuan pengelola sampah dalam menangani sampah tidak seimbang dengan produksinya. ${ }^{1}$

Menurut Pasal 1 angka (1) UU No. 18 Tahun 2008 tentang Pengelolaan Sampah manusia dan/atau proses alam yang berbentuk padat. Sedangkan menurut Pasal 1 angka (5) Pengelolaan sampah adalah kegiatan yang sistematis,menyeluruh, dan berkesinambunganyang meliputi pengurangandan penanganan sampah. Pengelolaan sampah juga diatur dalam Qanun No.3 Tahun 2014, Pasal 1 No.14 yaitu Pengelolaan Sampah adalah kegiatan yang sistematis, menyeluruh, dan berkesinambungan yang meliputi perencanaan, pengurangan, dan penanganan sampah. Sehingga pengelolaan pada kawasan perkotaan, dewasa ini dihadapkan kepada berbagai permasalahan yang cukup kompleks. Permasalahanpermasalahan tersebut meliputi tingginya laju timbunan sampah, kepedulian masyarakat (human behaviour) yang masih sangat rendah serta masalah pada kegiatan pembuangan akhir sampah.

Selain hal tersebut di dalam masyarakat perkotaan terdapat budaya konsumtif yang mempengaruhi dalam peningkatan kualitas dan jenis sampah. Sehingga dalam pengelolaan sampah tidak akan dapat dipisahkan dengan campur tangan negara dan berbagai sektor yang ada di dalam masyarakat termasuk dunia usaha.

Selain itu peran dari masayarakat yang merupakan jejaring atau komunitas pembuang sampah juga mempunyai andil besar dalam pengelolaan sampah dalam hal ini adalah proses daur ulang untuk dapat dimanfaatkan kembali. Sehingga dalam pengelolaan sampah

\footnotetext{
${ }^{1}$ Waluyo, Ayub Torry Satriyo Kusumo, Rosita Candrakirana. Laporan Penelitian Hibah Bersaing dengan judul Model Pengelolaan Sampah Kota Berbasis Gender Sebagai Upaya Pengentasan Kemiskinan. (Surakarta: Fakultas Hukum Universitas Sebelas Maret, 2012).
} 
merupakan bagian dari pelayanan publik yang harus diatur dalam regulasi yang diharapkan akan memberikan kenyamanan di dalam kehidupan masyarakat warga sehari-hari.

Kebijakan berupa pengaturan di Indonesia dirasa belum efektif menimbulkan efek jera kepada masyarakat. Hal tersebut dibuktikan dengan jumlah penduduk 237 juta yang diperkirakan akan bertambah menjadi 270 juta penduduk di tahun 2025, diperkirakan jumlah sampah yang akan dihasilkan sebanyak 130.000 ton/hari. ${ }^{2}$ Selain itu Indonesia juga didaulat sebagai negara peringkat ke-2 penghasil sampah domestik yaitu sebesar 5,4 juta ton per tahun. Permasalahan pengelolaan sampah sudah menjadi permasalahan yang krusial karena daerah-daerah (Kabupaten/Kota) juga mengalami banyak kendala dalam pengelolaan sampah. Salah satu hal yangmenjadi kendala mengenai penerapan dan penegakan hukum dalam pengelolaan sampah yang merupakan bagian dari penegakan hukum lingkungan terutama dalam penerapan sanksinya.

Di Indonesia sebenarnya terdapat beberapa peraturan perundang-undangan yangmempunyai korelasi maupun berkaitan langsung dengan pengelolaan sampah yaitu Undang-Undang No. 32 Tahun 2009 tentang Perlindungan dan Pengelolaan Lingkungan Hidup, Undang-undang, Nomor 32 tahun 2004 tentang Pemerintahan. Daerah diganti dengan UU No. 23 Tahun 2014 tentang Pemerintahan Daerah, UU No. 18 Tahun 2008 tentang Pengelolaan Sampah dan beberapa peraturan daerah yang sudah dibentuk oleh pemerintah daerah baik di tingkat Kabupaten atau Kota seperti di Peraturan Daerah Kota Langsa yang tertuang dalam QanunNo. 3 tahun 2014 Tentang Pengelolaan Sampah.

Selain itu peran pemerintah daerah Kota Langsa juga sangat penting dalam mengeluarkan kebijakan terhadap pengelolaan sampah. Apabila daerah mampu mengelola sampahnya dengan baik maka pelaksanaan terhadap prinsip Good Environmental Governance sudah dapat dikatakan terpenuhi.Berdasarkan latar belakang masalah di atas penulis dapat merumuskan masalah sebagai berikut Bagaimana pengelolaan sampah di Kota Langsa untuk memenuhi prinsip Good Environmental Governance.

\section{Metode Penelitian}

Penelitian yang dilakukan adalah penelitian yang bersifat Deskriptif. Jenis penelitian dalam penulisan ini termasuk jenis penelitian hukum doktrinal/normatif. Sedangkan jika dilihat dari sifatnya termasuk penelitian deskriptif dan menurut bentuknya penelitian ini merupakan penelitian diagnostik yakni penelitian yang bertujuan untuk mendapatkan keterangan mengenai sebab-sebab terjadinya suatu gejala atau beberapa gejala. Tehnik pengumpulan data dilakukan dengan studi kepustakaan untuk mengumpulkan dan menyusun data yang berhubungan dengan masalah yang diteliti. Data yang diperoleh dalam penulisan

\footnotetext{
${ }^{2}$ Rosita Candra Kirana, penegakan hukum lingkungan dalam bidang pengelolaan sampah sebagai perwujudan prinsip good environmental governance di kota Surakarta, Surakarta:Universitas 11 Maret. Jurnal Lingkungan Hidup. 2015
} 
ini bersifat kualitatif, maka analisis dalam penulisan ini adalah analisis data kualitatif dengan pendekatan masalah yaitu Statute Approach (Pendekatan Perundang-undangan). ${ }^{3}$

Dalam hal ini suatu penelitian normatif tentu harus menggunakan pendekatan perundang-undangan, karena yang akan diteliti adalah berbagai aturan hukum yang menjadi fokus sekaligus tema sentral suatu penelitian

\section{Hasil Penelitian dan Pembahasan}

\section{Pengaturan Pengelolaan Sampah di Kota Langsa}

Problematika mengenai sampah merupakan hal yang sangat penting. Sampah merupakan hal berkaitan dengan budaya dan perilaku masyarakat terutama di wilayah perkotaan. Untuk itu perlu pengelolaan sampahyang benar sesuai dengan peraturan perundang-undangan yang ada. Permasalahan sampah menjadi masalah penting di berbagai wilayah perkotaan (khususnya) yang padat penduduknya.

Hal tersebut dikarenakan sebagian besar masyarakat masih memandang bahwa sampah merupakan sisa dari penggunaan suatu barang baik itu organik maupun anorganik yang tidak dapat dimanfaatkan. Sehingga masyarakat dalam mengelola sampah masih bertumpu pada pendekatan akhir (end - of - pipe ), yaitu sampahdikumpulkan, diangkut, dan dibuang ketempat pemrosesan akhir sampah. Padahal, timbunan sampah dengan volume yang besar di lokasi tempat pemrosesan akhir sampah berpotensi melepas gas metan $(\mathrm{CH} 4)$ yang dapat meningkatkan emisi gas rumah kaca dan memberikan kontribusi terhadap pemanasan global. Agar timbunan sampahdapat terurai melalui proses alam diperlukan jangka waktu yang lama dan diperlukan penanganan dengan biaya yang besar. Dalam pengelolaan sampah pemerintah maupun pemerintah daerah memerlukan kebijakan dalam bidang regulasi yang didasarkan pada peraturan-peraturan tingakat nasional maupun daerah, peraturan tersebut antara lain :

a. Pasal $28 \mathrm{H}$ ayat (1) Undang-Undang Dasar Negara Republik Indonesia Tahun 1945

Pasal 28H ayat (1) Undang-Undang Dasar Negara Republik Indonesia Tahun1945 memberikan hak kepada setiap orang untuk mendapatkan lingkungan. Hal itu membawa konsekuensi hukum bahwa pemerintah merupakan pihak yang berwenang dan bertanggung jawab di bidang pengelolaan sampah.

Meskipun pengelolaan sampah merupakan kewajiban pemerintah akan tetapi hal tersebut juga dapat melibatkan dunia usaha dan masyarakat yang bergerak dalam bidang persampahan.Dalam rangka menyelenggarakan pengelolaan sampah secara terpadu dan komprehensif, pemenuhan hak dan kewajiban masyarakat, serta tugas

\footnotetext{
${ }^{3}$ Peter Mahmud Marzuki, Penelitian Hukum Normatif, (Jakarta : Kencana Prenada Media Group, 2010), hlm. 96.
} 
dan wewenang Pemerintah dan pemerintahan daerah untuk melaksanakan pelayanan publik, diperlukan payung hukum dalam bentuk undang-undang.

Pengaturan hukum pengelolaan sampah dalam Undang-Undang ini berdasarkan asas tanggung jawab, asas berkelanjutan, asas manfaat, asas keadilan, asas kesadaran, asas kebersamaan, asas keselamatan, asas keamanan, dan asas nilai ekonomi.

\section{b. Undang-undang Nomor 32 Tahun 2004 tentang Pemerintahan Daerah dicabut oleh Undang-undang Nomor 23 Tahun 2014 tentang Pemerintahan Daerah}

Berdasarkan amanah Pasal 18 ayat (2) dan ayat (5) Undang-Undang Dasar Negara Republik Indonesia Tahun 1945 menyatakan bahwa Pemerintahan Daerah berwenang untuk mengatur dan mengurus sendiri urusan Pemerintahan menurut Asas Otonomi dan Tugas Pembantuan dan diberikan otonomi yang seluas-luasnya. Atas dasar pasal tersebut beserta penjelasannya penyelenggaraan pemerintahan daerah harus didasarkan pada azas desentralisasi, dekonsentrasi, dan tugas pembantuan.

Sehingga adanya UU No. 32 Tahun 2004 yang mengatur mengenai kewenanganpemerintah daerah baik Provinsi maupun Kabupaten/Kota terkait pengendalian lingkungan hidup. Meskipun UU tersebut diganti dengan UU No. 23 Tahun 2014 tetap memberikan kewenangan kepada pemerintah daerah. Dalam Pasal 12 UU No. 23 Tahun 2014 bahwa kewenangan kepada pemerintah daerah (pemerintah konkuren) untuk menjalankan urusan pemerintahan wajib yang tidak berkaitan dengan Pelayanan Dasar salah satunya adalah lingkungan hidup.

Denganadanya pemberianotonomi yang seluas-luasnya kepada Daerah diarahkan untuk mempercepat terwujudnya kesejahteraanmasyarakat melalui peningkatanpelayanan, pemberdayaan, dan peran serta masyarakat. Sehingga kewenangan dalam penglolaan sampah merupakan sebuah pelayanan yang diberikan pemerintah daerah dengan memberdayakan serta pengelolaan sampah yang berbasis partisipasi masyarakat.

\section{c. Undang-Undang No. 32 Tahun 2009 tentang Perlindungan dan Pengelolaan Lingkungan Hidup (UUPPLH)}

Pemenuhan lingkungan hidup yang baik dan sehat merupakan hak asasi dan hak konstitusional bagi setiap warga negara Indonesia. Oleh karena itu, pemerintah, pemerintah daerah dan seluruh pemangku kepentingan berkewajiban untuk melakukan perlindungan dan pengelolaan lingkungan hidup dalam pelaksanaan pembangunan berkelanjutan agar lingkungan hidup Indonesia dapat tetap menjadi sumber dan penunjang bagi kehidupan rakyat Indonesia serta makhluk hidup lain. Sehingga pengelolaan sampah yang baik dan benar merupakan wujud dari pemenuhan lingkungan hidup yang baik dan sehat. Berkaitan dengan pengelolaan sampah bagi pemerintah dan pemerintah daerah tidak dapat lepas dari asas-asas yang 
terdapat dalam Pasal 2 UU PPLH yang diatur mengenai asas tanggung jawab negara, asas partisipatif, asas tata kelola pemerintahan yang baik; dan asas otonomi daerah. Oleh karena itu pengelolaan sampah merupakan wujud tanggungjawab negara melalui pemerintah dan pemerintah daerah.Dimana dibutuhkan partisipasi masyakat untuk melakukan pengelolaannya. Selain itu diperkuat dengan Pasal 63 UU PPLH yang mengatur mengenai kewenanganpemerintah dan pemerintah daerah dalam perlindungan dan pengelolaan lingkungan hidup. Dimana berdasarkan asas tata kelola pemerintahan yang baik; dan asas otonomi daerah dapat dijadikan acuan dalam pengelolaan sampah.

\section{d. Undang-undang No 18 Tahun 2008 tentang Pengelolaan Sampah}

Dalam UU Pengelolaan sampah didasari dengan Jumlah penduduk Indonesia yang besar dengan tingkat pertumbuhan yang tinggi mengakibatkan bertambahnya volume sampah. Di samping itu, pola konsumsi masyarakat memberikan kontribusi dalam menimbulkan jenis sampah yang semakin beragam, antara lain, sampah kemasan yang berbahaya dan/atau sulit diurai oleh proses alam semakin beragam. Substansi UU ini yang terkait dengan langsung mengenai pengelolan sampah yaitu Pasal 19 mengatur mengenai pengelolaan sampah rumah tangga dan sampah sejenis sampah rumah tangga. Pasal tersebut menyebutkan bahwa pengelolaan sampah rumah tangga dan sampah sejenis sampah rumah tangga terdiri atas pengurangan sampah dan penanganan sampah.

Dalam hal pengurangan sampah, lebih lanjut disebutkan dalam Pasal 20 sebagai berikut : Pengurangan sampah yang dimaksud dalam meliputi kegiatan: yang dimaksud dalam meliputi kegiatan: (1) pembatasan timbulan sampah; (2) pendauran ulang sampah; dan/atau (3) pemanfaatan kembali sampah. Dalam Pasal 20 ayat (2) diatur mengenai pemerintah dan pemerintah daerah wajib melakukan kegiatan sebagai berikut: (1) menetapkan target pengurangan sampah secara bertahap dalam jangka waktu tertentu; (2) memfasilitasi penerapan teknologi yang ramah lingkungan; (3) memfasilitasi penerapan label produk yang ramah lingkungan; (4) memfasilitasi kegiatan mengguna ulang dan mendaur ulang; (5) memfasilitasi pemasaran produk-produk daur ulang.

Pasal 20 ayat (3) mengatur mengenai pelaku usaha dalam melaksanakan kegiatan yaitu menggunakan bahan produksi yang menimbulkan sampah sesedikit mungkin, dapat diguna ulang, dapat didaur ulang, dan/atau mudah diurai oleh proses alam. Pasal 20 ayat (4) mengatur mengenai masyarakat dalam melakukan kegiatan pengurangan sampah yaitu menggunakan bahan yang dapat diguna ulang, didaur ulang, dan/atau mudah diurai oleh proses alam.

Pasal 22 Undang Nomor 18 Tahun 2008 mengatur mengenai pengelolaan sampah tersebut juga diatur mengenai mengenai penanganan sampah, yang meliputi : 
1) pemilahan dalam bentuk pengelompokan dan pemisahan sampah sesuai dengan jenis, jumlah, dan/atau sifat sampah;

2) pengumpulan dalam bentuk pengambilan dan pemindahan sampah dari sumber sampah ke tempat penampungan sementara atau tempat pengolahan sampah terpadu;

3) pengangkutan dalam bentuk membawa sampah dari sumber dan/atau dari tempat penampungan sampah sementara atau dari tempat pengolahan sampah terpadu menuju ke tempat pemrosesan akhir;

4) pengolahan dalam bentuk mengubah karakteristik, komposisi, dan jumlah sampah; dan/atau

5) pemrosesan akhir sampah dalam bentuk pengembalian sampah dan/atau residu hasil pengolahan sebelumnya ke media lingkungan secara aman.

e. Ketentuan yang diatur dalam penyelenggaraan pengelolaan sampah dalam UU No 18 Tahun 2008 tentang Pengelolaan Sampah

Seharusnya mampu menangani permasalahan mengenai sampah di Indonesia. Sudah menjadi umum bahwa selama ini manajemen sampah masih menerapkan konsep Kumpul-Angkut-Buang (end of pipe). Dengan adanya UU ini, maka manajemen sampah telah mengadopsi konsep 3R: Reduction (Kurangi)-Reuse (gunakan kembali)-Recycling (daur ulang). Demikian halnya dengan paradigma manajemen sampah, bila selama ini menggunakan konsep konvensional yakni sampah dianggap limbah sehingga dibuang yang memerlukan ongkos pembuangan dan pada akhirnya menjadi ancaman kesehatan bagi masyarakat. Maka sekarang digunakan paradigma baru yang memandang sampah sebagai sumber daya yang seharusnya diolah kembali sehingga menghasilkan pendapatan yang bermuara pada kesempatan terbukanya lapangan kerja baru dan kesempatan mendapatkan penghasilan baru.

\section{f. Qanun Kota Langsa Nomor 03 Tahun 2014 tentang Pengelolaan Sampah}

Dalam penjelasan Qanun Kota Langsa No. 3 Tahun 2014 disampaikan latar belakang pentingnya pengelolaan sampah di daerah khususnya di Kota Langsa. Faktor yang menjadi pentingnya pengelolaan sampah karena semakin tingginya pertambahan penduduk dan meningkatnya aktivitas kehidupan masyarakat di Kota Langsa, berakibat semakin banyak timbulnya sampah, yang jika tidak dikelola secara baik dan teratur bisa menimbulkan berbagai masalah, bukan saja bagi Pemerintah Daerah tetapi juga bagi seluruh masyarakat. Sampah sebagai sumber daya yang mempunyai nilai ekonomi dan dapat dimanfaatkan.Pengelolaan sampah diselenggarakan berdasarkan asas tanggung jawab, asas berkelanjutan, asas manfaat, asas keadilan, asas kesadaran, asas kebersamaan, asas keselamatan, asas keamanan, 
dan asas nilai ekonomi.Pengelolaan sampah dengan paradigma baru tersebut dilakukan dengan kegiatan pengurangan dan penanganan sampah.

Pengurangan sampah meliputi kegiatan pembatasan, penggunaan kembali, dan pendauran ulang, sedangkan kegiatan penanganan sampah meliputi pemilahan, pengumpulan, pengangkutan, pengolahan, dan pemrosesan akhir. Pemerintah merupakan pihak yang berwenang dan bertanggung jawab di bidang pengelolaan sampah meskipun secara operasional pengelolaannya dapat bermitra dengan badan usaha.

Selain itu organisasi persampahan, dan kelompok masyarakat yang bergerak di bidang persampahan dapat juga diikut sertakan dalam kegiatan pengelolaan sampah. Pengelolaan sampah di wilayah Kota Langsa salah satunya adalah usaha untuk mewujudkan Kota Langsa dengan pengelolaan sampah secara terpadu dan komprehensif; terjaminnya kesehatan masyarakat; dan terpelihara kualitas lingkungan; selain itu diharapkan terciptanya sampah sebagai sumber daya; sehingga terwujudnya perilaku masyarakat yang baik dalam pengelolaan sampah.

\section{Kebijakan Pemerintah Pengelolaan Sampah Di Kota Langsa Untuk Memenuhi Prinsip Good Environmental Governance}

Menurut Azizy menyebutkan salah satu nilai yang menjadi prinsip dari good governance adalah komitmen terhadap perlindungan lingkungan hidup. Prinsip tersebut ditekankan pada keseimbangan antara pemanfaatan sumber daya alam dan perlindungan/ konservasinya, penegakan prinsip-prinsip pembangunan berkelanjutan, rendahnya tingkat pencemaran dan kerusakan lingkungan, dan rendahnya tingkat pelanggaran terhadap aktivitas perusakan lingkungan. ${ }^{4}$

Environmental governance merupakan paradigma baru di bidang lingkungan hidup dimana menjadi bagian penting dari pencapaian good governance. Selain itu konsep enviromental governance diharapkan dapat menjadikan aspek lingkungan sebagai mainstream utama pembangunan di indonesia yang sama-sama menjalankan aspek ekonomi dan sosial.

Untuk mengetahui definisi terkait environmental governance, Mugabe dan Tumushabe menegaskan mendasarkan pemahaman terkait environmental governance pada dua konsep yakni dimaksud adalah sebuah kumpulan nilai-nilai dan norma yang memandu atau mengatur hubungan antara negara dan masyarakat dalam penggunaan, pengawasan dan manajemen dari lingkungan alam. ${ }^{5}$

${ }^{4}$ Ahmad Qodri Abdillah Azizy, Change Management Dalam Reformasi Birokrasi, (Jakarta: PT. Gramedia Utama, 2007), hlm. 47

${ }^{5}$ Ibid., hlm 8 
Guna memantapkan implementasi Environmental governance yakni adanya lembaga perwakilan yang mampu menjalankan fungsi sebagai legislator dan kontrol efektif, peradilan independen, bersih, mandiri dan profesional, aparatur pemerintahan yang memiliki integritas dan profesionalitas, desentralisasi yang demokratis, masyrakat sipil yang kuat sehingga mampu melaksanakan tugas kontrol politik yang efektif dan mekanisme resolusi konflik yang efektif pula. ${ }^{6}$

Salah satu kebijakan pemerintah mengenai permasalahan sampah yang dapat di daur ulang yaitu bekerjasama dengan bank sampah kota Langsa yang berada di Kecamatan Langsa Barat yang memiliki sarana prasarana untuk pengelolaan sampah. Sejalan dengan perkembangan organisasi pada pemerintah dan hubungan sampah dengan lingkungan hidup, dibentuklah suatu badan yang dikhususkan untuk mengelola lingkungan atau unit yag berada di Kecamatan Langsa Timur tepatnya di Gampong Alue Pineung. Pada prinsipnya, pengelolaan sampah perkotaan dapat dilakukan oleh unit atau badan apapun asalkan terdapat pembagian kerja, program, dan standar operasional prosedur (SOP) yang jelas. Hal yang terpenting adalah tujuan dari pengelolaan sampah tercapai. Di Kota Langsa juga terdapat dinas tertentu untuk bertanggung jawab terhadap pengelolaan sampah. Hal tersebut sesuai dengan penelitian yang dilakukan di Kota Langsa bahwa penanganan sampah domestik umumnya ditangani oleh Dinas Kebersihan dan Pertamanan Kota Langsa.

Regulasi sebagai dasar kegiatan pelayanan yang diberikan oleh pemerintah kepada masyarakat tentang pengelolaan sampah diwujudkan dalam bentuk peraturan perundangan di setiap kecamatan. Regulasi tersebut sebagai dasar hukum pelaksanaan kegiatan dan berperan sebagai aturan yang harus ditaati oleh masyarakat. Selain itu kebijakan lainnya yaitu upaya penegakan hukum (law enforcement) dikatakan sebagai salah satu upaya peningkatan partisipasi. Kesadaran masyarakat terhadap regulasi akan sangat membantu upaya pengelolaan sampah.

Penegakan hukum menjadi salah satu pembangun budaya sadar lingkungan. Budaya tersebut diwujudkan dengan membuat peraturan perundangan (regulasi), pembatasan wilayah, dan pemberian kompensasi ekonomi berupa insetif dan disinsentif. Reward atau insentif dalam penegakan hukum dibutuhkan. Insentif merupakan motivasi dan pendukung profesionalisme dalam bekerja. Hal tersebut perlu mendapatkan perhatian apabila menghendaki kerja yang optimal dari orang yang bekerja untuk perusahaan tersebut. Dalam menumbuhkan kesadaran masyarakat dalam pengelolaan sampah maka dibutuhkan adanya sebuah kebijakan. Oleh karena itu kebijakan adalah sarana yang didalamnya terkandung nilai-nilai dan konsep-konsep tentang keadilan, kebenaran, kemanfaatan sosial dan sebagainya. $^{7}$

\footnotetext{
${ }^{6}$ Slamet Muljono, Pendidikan Lindkungan Hidup Bagi Pimpinan Aparatur Pemerintahan Dalam Mewujudkan Good Governance, Jurnal Widyaprana Volume 1, No. 2 Desember 2008, hlm. 98

${ }^{7}$ Ridwan HR., Hukum Administrasi Negara Edisi Revisi, (Jakarta : PT. Grafindo Persada, 2011) hlm. 291
} 
Upaya pemerintah dalam penegakan hukum di bidang pengelolaan sampah memang faktor terbesar adalah budaya dalam masyarakat. Selain itu pemerintah kota Langsa juga mempunyai andil yang besar dalam upaya penegakan hukum dibidang pengelolaan sampah baik secara preventif maupu represif. Selain itu substansi hukum yang ada yaitu Qanun Nomor 03 Tahun 2014 sebenarnya sudah baik sehingga diperlukan adanya sosialisasi dari pemerintah kota Langsa kepada masyarakat mengenai aturan tersebut. Untuk itu akan mewujudkan budaya hukum di masyarakat akan pentingnya pengelolaan sampah yang baik untuk menciptakan lingkungan yang baik dan sehat. Pengelolaan sampah yang baik, pada dasarnya adalah merupakan perwujudan penyelenggara pemerintahan yang baik dalam rangka untuk mewujudkan Good Environmental Governance (GEG). Penyelenggaraan pemerintahan berdasarkan prinsip good environmental governance memberikan makna bahwa prinsip-prinsip penyelenggaraan negara yang baik dalam mengelola lingkungan sesuai prinisp sumber-sumber daya alam dan lingkungan. ${ }^{8}$

Pelaksanaan prinsip-prinsip GEG merupakan perwujudan pemerintah dan pemerintah daerah dalam mendukung terciptanya lingkungan hidup baik dan untuk mewujudkan pelaksanaan pembangunan berkelanjutan. Dasar pelaksanaan prinsip-prinsip GEG ini adalah Pasal 63 UU PPLH yang mana pasal tersebut diatur mengenai kewenangan pemerintah dan pemerintah daerah dalam mengelola lingkungan hidup. Hal tersebut sejalan dengan pendapat Sonny Kerap yang menegaskan bahwa ada hubungan erat antara penyelenggaraan yang baik dengan pengelolaan lingkungan hidup yang baik. Penyelenggaraan pemerintahan yang baik akan mempengaruhi dan menentukan pengelolaan lingkungan hidup yang baik, dan pengelolaan lingkungan hidup yang baik mencerminkan tingkat penyelenggaraan pemerintahan yang baik. Tegasnya, tanpa penyelenggaraan pemerintahan yang baik, sulit mengharapkan akan adanya pengelolaan lingkungan hidup yang baik .

Sehingga pelaksanaan prinsip-prinsip GEG juga dapat mendukung dalam pengelolaan sampah oleh pemerintah dan pemerintah daerah. Adapun unsur-unsur penting di dalam kerangka GEG adalah sebagai berikut: ${ }^{9}$

1. Kedaulatan

2. Kekuatan

3. Kebijakan

4. Pengendalian

5. Pengembangan

6. Tanggung jawab

Unsur-unsur dalam prinsip GEG dapat menjadi acuan oleh pemerintah dan masyarakat dalam pengelolaan sampah dalam upaya penegakan hukum lingkungan baik secara preventif maupun represif dalam pengelolaan sampah. Kebijkan pemerintah dalam upaya pengelolaan sampah juga kriteria prinsip-prinsip good environmental governance:

\footnotetext{
${ }^{8}$ NHT Siahaan. Hukum Lingkungan, (Jakarta: Pancuran Alam, 2009), hlm. 143.

${ }^{9}$ NHT Siahaan. Ibid. hlm. 199.
} 

a. Pemberdayaan masyarakat.
b. Transparansi.
c. Desentralisasi yang demokratis
d. Pengakuan terhadap keterbatasan daya dukung ekosistem dan keberlanjutan.
e. Pengakuan hak masyarakat adat dan masyarakat setempat.

\title{
Penutup
}

Pengaturan mengenai pengelolaan sampah di Indonesia diatur dalam peraturan tingkat pusat dan daerah. Peraturan ditingkat pusat yang mempunyai korelasi terhadap pengelolaan sampah maupun berkaitan langsung dengan pengelolaan sampah yaitu Undang-Undang No. 32 Tahun 2009 tentang Perlindungan dan Pengelolaan Lingkungan Hidup, Undang-undang Nomor 23 tahun 2014 tentang Pemerintahan Daerah, UU No. 18 Tahun 2008 tentang Pengelolaan Sampah dan beberapa peraturan daerah yang sudah dibentuk oleh pemerintah daerah baik di tingkat Kabupaten/Kota contohnya Peraturan kota Langsa yang tertuang dalam Qanun No. 3 Tahun 2014 tentang Pengelolaan Sampah. Dalam peraturan-peraturan tersebut diatur mengenai penyelenggaraan pengelolaan sampah yaitu dengan pengurangan dan penanganan sampah yang melibatkan berbagai elemen baik dari pemerintah dan pemerintah daerah serta masyarakat untuk menciptakan lingkungan hidup yang baik dan sehat.

kebijakan pemerintah dalam pengelolaan sampah baik mengenai bank sampah maupun Penegakan hukum lingkungan dibidang pengelolaan sampah mengacu pada 3 sistem hukum yang merupakan gabungan dari komponen-komponen yaitu struktur, substansi dan culture/budaya. Selain itu berkaitan dengan penegakan hukum dalam pengelolaan sampah dapat dikaji dari 2 sisi yaitu penegakan hukum secara preventif dan represif. Penegakan hukum dalam pengelolaan sampah juga menjadi sebuah perwujudan pemerintah maupun pemerintah kota Langsa dalam menerapkan prinsip Good Environmental Governance dengan tujuan akan menumbuhkan kesadaran bagi masyarakat akan pentingya pengelolaan sampah.

\section{Daftar Pustaka}

\author{
Ahmad Qodri Abdillah Azizy, Change Management Dalam Reformasi Birokrasi, \\ Jakarta: PT. Gramedia Utama, 2007 \\ Siahaan NHT., Hukum Lingkungan, Jakarta: Pancuran Alam, 2009 \\ Peter Mahmud Marzuki, Penelitian Hukum Normatif, Jakarta : Kencana Prenada \\ Media Group, 2010
}


Ridwan HR., Hukum Administrasi Negara Edisi Revisi, Jakarta : PT. Grafindo Persada, 2011

Rosita Candra Kirana, penegakan hukum lingkungan dalam bidang pengelolaan sampah sebagai perwujudan prinsip good environmental governance di kota Surakarta, Surakarta:Universitas 11 Maret. Jurnal Lingkungan Hidup. 2015

Slamet Muljono, Pendidikan Lindkungan Hidup Bagi Pimpinan Aparatur Pemerintahan Dalam Mewujudkan Good Governance, Jurnal Widyaprana Volume 1, No. 2 Desember 2008

Waluyo, Ayub Torry Satriyo Kusumo, Rosita Candrakirana. Laporan Penelitian Hibah Bersaing dengan judul Model Pengelolaan Sampah Kota Berbasis Gender Sebagai Upaya Pengentasan Kemiskinan. Surakarta: Fakultas Hukum Universitas Sebelas Maret, 2012 